\title{
OCCUPATIONAL EXPOSURE TO RESPIRABLE CRYSTALLINE SILICA IN THE IRANIAN MAZANDARAN PROVINCE INDUSTRY WORKERS
}

\author{
Mahmoud MOHAMMADYAN ${ }^{1}$, Mohammad ROKNI², and Razieh YOSEFINEJAD ${ }^{3}$ \\ Health Sciences Research Center', Quemshahr Health Center ${ }^{2}$, Department of Occupational Health ${ }^{3}$, Mazandaran \\ University of Medical Sciences, Sari, Iran
}

Received in June 2012

CrossChecked in September 2012

Accepted in December 2012

\begin{abstract}
This study investigated occupational exposure to silica dust of 48 workers in stone cutting, glass making, ceramic, and sand blasting plants in the north of Iran. Samples were collected from the breathing zone using a personal sampling pump and a size-selective cyclone. Sample filters and blanks were analysed using infrared spectroscopy. The mean sampling period was $4.83 \mathrm{~h}$. Mean exposure of workers to crystalline silica dust in glass making, ceramic, sand blasting, and stone cutting was $0.129 \mathrm{mg} \mathrm{m}^{-3}, 0.169 \mathrm{mg} \mathrm{m}^{-3}$, $0.313 \mathrm{mg} \mathrm{m}^{-3}$ and $0.318 \mathrm{mg} \mathrm{m}^{-3}$, respectively. As exposure at each of the workplaces is three to 12 times higher than the current national and international thresholds, these workers run a greater risk of lung cancer and mortality. Our findings call for specific ventilation design and personal protection improvements in the four plants as well as stricter enforcement of the existing regulations by the authorities.
\end{abstract}

KEY WORDS: glass making, sand blasting, stone cutting, worker exposure

Crystalline silica is a basic component of soil, sand, granite, and many other minerals, mainly in the form of quartz (silicon dioxide or $\mathrm{SiO}_{2}$ ) as the most common mineral in the continental crust. Quartz is almost always clear or white, and if found in crystals, always has a hexagonal cross-section. Chipped, cut, drilled, or ground, its particles may become respirable (1). There is a strong body of evidence for a causal relationship between exposure to crystalline silica and a range of diseases, including silicosis, lung cancer, renal disease, kidney cancer, chronic obstructive pulmonary disease (COPD), scleroderma, rheumatoid arthritis, polyarthritis, mixed connective tissue disease, systemic lupus erythematosus, Sjogren's syndrome, polymyositis, fibrositis, cor pulmonale, lymphatic cancers (leukaemia, lymphomas), stomach and/or gastrointestinal malignancies, dermatomyosistis, and glomerulonephritis (2-10). Exposure to crystalline silica dust also causes silica dust-associated tuberculosis (TB) in developing and in some high-income countries (11). There is a reliable relationship between cumulative silica dust exposure and increased mortality from lung cancer (12). This increase in lung cancer occurrence is independent of smoking (13).

The US National Institute for Occupational Safety and Health (NIOSH) has set the exposure limit to $0.05 \mathrm{mg} \mathrm{m}^{-3}$ (for a 10-hour workday during a 40 hour week). The American Conference of Governmental Industrial Hygienists (ACGIH) has reduced this to the threshold limit value - time weighted average (TLVTWA) of $0.025 \mathrm{mg} \mathrm{m}^{-3}$ (14). Historically, until 1970 analysis of collected crystalline silica samples was an integral part of hazard assessment. Prior to measurement of respirable crystalline silica particles, in North America silica dust was measured using the impinger method, and was compared with TLV expressed in 
millions of particles per cubic foot of air (15). In 1970, the gravimetric respirable dust standard still expressed the percentage of crystalline silica in the sample for use in the denominator of the TLV formula, which for respirable dust was $10 \mathrm{mg} \mathrm{m}^{-3}$ divided by the percentage of respirable quartz plus two and for total dust $30 \mathrm{mg} \mathrm{m}^{-3}$ divided by the percentage of quartz plus three. In addition to the gravimetric method for sampling respirable crystalline silica dust, X-ray diffraction (XRD), infrared (IR) and ultraviolet-visible spectrophotometry (UV-VIS) methods are applied to measure crystalline silica directly on a sampling filter (16).

This article reports personal exposure to respirable silica particles in stone cutting, glass making, ceramic, and sand blasting industry workers in the Mazandaran province in the north of Iran. Exposure was determined from respirable particle samples collected on PVC filters using the Fourier transform infrared spectrophotometry (FT-IR).

\section{MATERIALS AND METHODS}

In this cross-sectional study we measured personal exposure of 48 randomly selected workers from four industrial sectors ( 12 per sector) at the following work places: two glass-making, two ceramic production, three sand-blasting, and two stone-cutting, all located in the Mazandaran province of Iran. For the measurement we used personal sampling pumps (Apex Pro personal sampling pump, Casella, UK) to sample air through a size-selective cyclone (Respirable Dust Aluminum Cyclone, SKC, UK) at a flow of $2.5 \mathrm{~L} \mathrm{~min}^{-1}$ calibrated using a soap bubble meter. Respirable silica particles were collected on a polyvinyl chloride (PVC) filter $(37 \mathrm{~mm}, 5 \mu \mathrm{m}$ pore size). Cyclone and filter holders were placed in the workers' breathing zone, with the cyclone inlet turned downward. Pump flow rate was checked regularly by the operator to prevent any gross error during the sampling. As the sampling pumps had a built-in thermometer and barometer, we also recorded air temperature and atmospheric pressure throughout the sampling. To assess the volume of sampled air, we calculated the correction factor. A weighed blank filter was submitted for each group of filters and placed in a filter cassette to assess the presence of factors that might interfere with the analysis of crystalline silica in the main sample. Sample filters and blanks were analysed in the Mazandarn University of Medical

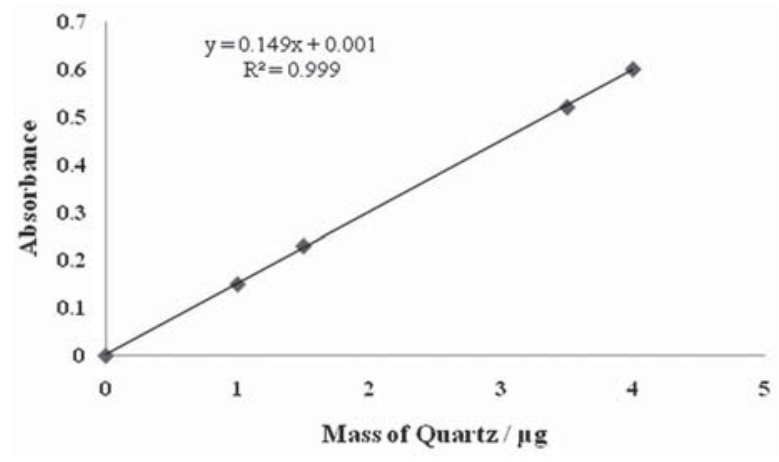

Figure 1 Infrared calibration curve for the standard quartz peaks at $800 \mathrm{~cm}^{-1}$

Sciences laboratory using infrared spectroscopy (NIOSH method no. 7602) (17). To assess the calibration curve, standards of crystalline silica were prepared by mixing $1 \mu \mathrm{g}, 1.5 \mu \mathrm{g}, 3.5 \mu \mathrm{g}$, and $4 \mu \mathrm{g}$ of crystalline silica with polyvinyl chloride filters. Filter samples, standards, and blanks were washed with $9 \%$ hydrochloric acid and burned in a muffle furnace at $600^{\circ} \mathrm{C}$. Three hundred milligrams of dried $\mathrm{KBr}$ was added to the burned material in a porcelain dish and mixed thoroughly with a pestle. Mixed powder (sample and $\mathrm{KBr}$ ) was then pressed into a pellet, and the pellet placed into the FT-IR (Perkin Elmer, Boston, USA). The validity of the method was tested in terms of coefficient of variation of triplicates of standard crystalline silica samples. For maximum sensitivity, absorbance of standards was measured at $800 \mathrm{~cm}^{-1}$ wavelength, and samples were quantified according to the regression formula of standard samples.

Standard sampled air volume was calculated by multiplying mean air flow with duration of sampling, atmospheric pressure and ambient temperature coefficients. Crystalline silica concentration in the workers' breathing zone is expressed as crystalline silica mass per standard sampled air volume.

\section{RESULTS AND DISCUSSION}

In order to obtain calibration curves for crystalline silica, quartz samples of respirable range were used as the standard. The absorption at $800 \mathrm{~cm}^{-1}$ is generally accepted as the most suitable band for analytical peak measurement, which is due to the symmetrical bending vibration of Si-O-Si. Therefore, an ordinary calibration curve is expressed as the graph of absorbance at 800 $\mathrm{cm}^{-1} v$ s. mass of quartz in a sample pellet, as shown in Figure 1. Mean sampling time was $4.83 \mathrm{~h}$ and ranged from $3.20 \mathrm{~h}$ to $6.20 \mathrm{~h}$, depending on the 
duration of workers' activities. In determining the eight-hour TWA exposure we conservatively assumed that occupational exposure to dust equalled zero for the time other than sampling time. The resulting eighthour TWA was then compared with the TLV of $0.025 \mathrm{mg} \mathrm{m}^{-3}$ mandated by ACGIH and recommended by the Iranian Technical Committee of Occupational Health under the term occupational exposure limit (OEL) (19).

Table 1 shows mean exposure of workers to crystalline silica dust in glass making, ceramic, sand blasting, and stone cutting. They are five to twelve times the TLV-TWA/OEL and increase in the following order: ceramic production, glass making, sand blasting, and stone cutting.

These findings are similar to those reported in other studies in Iran and other countries. Azari et al. (20) concluded that average occupational exposure of workers to crystalline silica in 10 industrial sectors in the east zone of Tehran ranged from $0.132 \mathrm{mg} \mathrm{m}^{-3}$ to $0.343 \mathrm{mg} \mathrm{m}^{-3}$. The lowest mean exposure was reported for glass manufacturing and the highest for foundry operations. Freeman et al. (21) studied silica exposure at workplaces in the United States between 1980 and 1992 and concluded that crystalline silica dust concentrations in industries such as glass and ceramic were higher than TLV. Another study carried out by Akbar-Khanzadeh and Brillhart (22) in the United States showed that $69 \%$ of workers in concrete finishing were overexposed to respirable crystalline silica dust. In Iran, Dehghan et al. (23) studied workers' exposure to silica dust in glass factory and obtained similar results as in our study. Only at five workplaces in our study (one in ceramic industry and four in glass making industry) was the exposure lower than the TLV.

Sand blasting and stone cutting were performed in the open under the shade. Only $20 \%$ of the stone cutting equipment used water jets to control silica dust.
At the other three workplaces, however, no dust control system was in place. A disposable cellulose filter was the only personal protective equipment used by workers in sand blasting and stone cutting. Glass was made traditionally in a hall $\left(600 \mathrm{~m}^{2}\right.$ of area, $6 \mathrm{~m}$ high) ventilated by a few fans and most of the workers did not use any protective equipment, save for mixer operators, who used disposable cellulose filters. Ceramic production was also run traditionally in a hall $\left(500 \mathrm{~m}^{2}\right.$ of area, $6 \mathrm{~m}$ high) ventilated by several wallfixed fans that did not reduce workers' exposure because they were working near emission sources. Workers in this factory did not use any personal protection equipment. Poor dust control, ventilation, and personal protection are therefore the major issues in these work environments. The largest improvement in exposure control would be an effective ventilation system complemented with respirators.

Clearly, occupational exposure to crystalline silica in our study increases the risk of lung cancer and mortality among workers. The first step in reducing this risk is to assess it (24). The second is to upgrade industrial processes, design an effective ventilation system, and enforce the use of personal protective equipment. The designing and operation of a local exhaust ventilation system may cost about 25,000 to 30,000 USD in the sand blasting and stone cutting factories and about 50,000 to 75,000 USD in the glass making and ceramic plants. All the four production plants are owned privately and the national Environmental Protection Agency should impose and enforce stricter regulations to control silica dust exposure.

\section{Acknowledgement}

This study was supported by the Mazandaran University of Medical Sciences.

Table 1 Workers' exposure to crystalline silica in four industrial sectors

\begin{tabular}{|c|c|c|c|c|}
\hline \multicolumn{4}{|c|}{ Concentration of crystalline silica / $\mathrm{mg} \mathrm{m}^{-3}$} & \multirow{2}{*}{ Industrial sector } \\
\hline Max & Min & SD & Mean & \\
\hline 0.423 & 0.004 & 0.129 & 0.125 & Glass making \\
\hline 0.254 & 0.003 & 0.065 & 0.169 & Ceramic \\
\hline 0.753 & 0.125 & 0.181 & 0.313 & Sand basting \\
\hline 0.597 & 0.071 & 0.122 & 0.318 & Stone cutting \\
\hline
\end{tabular}

Reference TLV-TWA/OEL $=0.025 \mathrm{mg} \mathrm{m}^{-3}$ 


\section{REFERENCES}

1. U.S. Department of Labor Occupational Safety and Health Administration (OSHA). "Crystalline Silica Exposure" Health Hazard Information for Construction Employees [displayed 13 July 2011]. Available at http://www.osha. gov/Publications/osha3177.pdf

2. Rosner D, Markowitz G. Deadly Dust: Silicosis and the OnGoing Struggle to Protect Workers health. $2^{\text {nd }}$ ed. Ann Arbor (MI): The University of Michigan Press; 2006.

3. American Thoracic Society. Adverse effects of crystalline silica exposure. Am J Respir Crit Care Med 1997;155:7618.

4. Calvert GM, Rice FL, Boiano JM, Sanderson WT. Occupational silica exposure and risk of various diseases: an analysis using death certificates from 27 states of the United States. Occup Environ Med 2003;60:122-9.

5. Goldsmith D. Relationship of exposures to crystalline silica and health effects: An Epidemiologist view of the controversy 2006 [displayed 13 July 2011]. Available at http://www.aiha. org/aihce06/handouts/rt241 goldsmith.pdf

6. Green FHY, Vallyathan V. Pathologic responses to inhaled silica. In: Castranova V, Vallyathan V, Wallace W E, editors. Silica and silica-induced lung diseases. Boca Raton (FL): CRC Press; 1996. p. 39-59.

7. International Agency for Research on Cancer (IARC). Silica. IARC Monographs Program on the Evaluation of the Carcinogenic Risk of Chemicals to Humans. Vol. 68. Lyon: IARC; 1997.

8. McDonald JC, McDonald AD, Hughes JM, Rando RJ, Weill H. Mortality from lung and kidney disease in a cohort of North American industrial sand workers: an update. Ann Occp Hyg 2005;49:367-73.

9. Rafnsson V, Ingimarsson O, Hjalmarsson I, Gunnarsdottir H. Association between crystalline silica exposure and risk of sarcoidosis. Occup Environ Med 1998;55:657-60.

10. Steenland K. One agent, many diseases: exposure-response data and comparative risks of different outcomes following silica exposure. Am J Ind Med 2005;48:16-23.

11. Rees D, Murray J. Silica, silicosis and tuberculosis. Int J Tuberc Lung Dis 2007;11:474-84.

12. Chen W, Yang J, Chen J, Bruch J. Exposures to silica mixed dust and cohort mortality study in tin mines: exposureresponse analysis and risk assessment of lung cancer. Am J Ind Med 2005;49:67-76.
13. Berry G, Rogers A, Yeung P. Silicosis and lung cancer: a mortality study of compensated men with silicosis in New South Wales, Australia. Occup Med 2004;54:387-94.

14. Centers for Disease Control and Prevention (CDC). NIOSH Workplace Safety and Health Topics, Silica [displayed 13 July 2011]. Available at http://www.cdc.gov/niosh/topics/ silica

15. Talvitie NA. Determination of free silica: gravimetric and spectrophotometric procedure applicable to air-borne and settled dust. Am Ind Hyg Assoc J 1964;25:169-78.

16. Federal Register. US code of Federal Regulations 29CFR1910.1200. Hazard communication. $1^{\text {st }}$ ed. Washington (DC). Federal Register National Archives and Records Administration; 1998.

17. The National Institute for Occupational Safety and Health (NIOSH). Silica, Crystalline by IR (KBr pellet) 7602. NIOSH manual of analytical methods. $4^{\text {th }}$ ed [displayed 13 July 2011]. Available at http://www.cdc.gov/niosh/docs/2003-154/ pdfs/7602.pdf

18. American Conference of Governmental Industrial Hygienists (ACGIH). Threshold Limit Values for Chemical Substances and Physical Agents and Biological Exposure Indices. Cincinnati (OH); ACGIH; 2008.

19. Iranian Technical Committee of Occupational Health (ITCOH). Occupational Exposure Limit for Chemical Substances. Tehran: ITCOH; 2012.

20. Azari MR, Rokni M, Salehpour S, Mehrabi Y, Jafari MJ, Moaddeli AN, Movahedi M, Ramazankhani A, Hatami H, Mosavian MA, Ramazani B. Risk assessment of workers exposed to crystalline silica aerosols in the east zone of Tehran. Tanaffos 2009;8:43-50.

21. Freeman CS, Grossman EA. Silica exposures in workplaces in the United States between 1980 and 1992. Scand J Work Environ Health 1997;21(Suppl 2):47-9.

22. Akbar- Khanzadeh F, Brillhart RL. Respirable crystalline silica dust exposure during concrete finishing (grinding) using hand-held grinders in the construction industries. Ann Occup Hyg 2002;46:341-6.

23. Dehghan HA, Rzavizadeh ND. Survey of free silica level in the workers' breathing zone in the Qazvin glass factory using X-ray diffraction. Iran J Pub Health 1999;4:121-32.

24. National Institute of Occupational Safety and Health (NIOSH). A guide to working safety with silica: if it's silica, it's not just 1997 [displayed 19 September 2011]. Available at http://www.cdc.gov/niosh/pdfs/silicax.pdf 


\title{
Sažetak
}

\section{PROFESIONALNA IZLOŽENOST RESPIRABILNIM ČESTICAMA KRISTALNOG SILICIJEVA DIOKSIDA U INDUSTRIJSKIH RADNIKA IRANSKE PROVINCIJE MAZANDARAN}

\begin{abstract}
Izmjerena je profesionalna izloženost prašini silicijeva dioksida u 48 radnika na rezanju kamena, proizvodnji stakla, proizvodnji keramike i pjeskarenju na sjeveru Irana. Uzorci su uzeti u zoni disanja s pomoću osobne pumpe i ciklona podešenog na odgovarajuću veličinu čestica. Filtri s uzorcima i slijepi uzorci analizirani su infracrvenom spektroskopijom. Srednje vrijeme uzorkovanja iznosilo je 4,83 h. Srednja razina izloženosti radnika prašinama kristalnog silicijeva dioksida iznosila je $0,129 \mathrm{mg} \mathrm{m}^{-3} \mathrm{u}$ proizvodnji stakla, $0,169 \mathrm{mg}$ $\mathrm{m}^{-3} \mathrm{u}$ proizvodnji keramike, $0,313 \mathrm{mg} \mathrm{m}^{-3} \mathrm{u}$ pogonu za pjeskarenje te $0,318 \mathrm{mg} \mathrm{m}^{-3}$ u pogonu za rezanje kamena. Budući da je ovakva izloženost na svim radnim mjestima tri do dvanaest puta viša od trenutačnih državnih i međunarodnih ograničenja, ovi su radnici izloženi povećanom riziku od raka pluća i smrtnosti. Naši rezultati potvrđuju potrebu za posebnim ventilacijskim sustavima i poboljšanom osobnom zaštitom u sva četiri pogona te za strožom provedbom postojećih zakonskih odredbi od strane nadležnih tijela.
\end{abstract}

KLJUČNE RIJEČI: pjeskarenje, proizvodnja stakla, rezanje kamena

\section{CORRESPONDING AUTHOR:}

Mahmoud Mohammadyan

Health Sciences Research Center

Mazandaran University of Medical Sciences, Sari, Iran

E-mail:mohammadyan@yahoo.com 